DOI:http//dx.doi.org/10.31558/2307-2296.2019.1.4

УДК 336.144

Гуменюк Р.П., аспірант кафедри фінансів і банківської справи Донецького національного університету ім. Василя Стуса

\title{
СВІТОВИЙ ДОСВІД МЕХАНІЗМІВ ФІНАНСОВОГО ЗАБЕЗПЕЧЕННЯ ЗБРОЙНИХ СИЛ
}

В умовах недостатнього фінансування потреб Міністерства оборони України дедалі актуальним стає розвиток програмно-цільового методу бюджетного планування, адже акцент переноситься 3 потреби в коштах для утримання збройних сил на те, які результати будуть досягнуті від використання бюджетних коштів, тобто забезпечується ефективність їх використання.

В статті розглянуто сутність, особливості і значення фінансового забезпечення збройних сил країн НАТО, що дуже важливо в умовах застосування програмно-цільового методу формування та виконання оборонного бюджету.

Ключові слова: бюджет, оборонне планування, бюджетні програми.

Рис. 1, Літ. 9

\section{Гуменюк Р.П.}

\section{МИРОВОЙ ОПЫТ МЕХАНИЗМОВ ФИНАНСОВОГО ОБЕСПЕЧЕНИЯ ВООРУЖЕННЫХ СИЛ}

В условиях недостаточного финансирования потребностей Министерства обороны Украины актуальным становится развитие программно-целевого метода бюджетного планирования, ведь акцент переносится из потребности в средствах для содержания вооруженных сил на то, какие результаты будут достигнуты от использования бюджетных средств, то есть обеспечивается эффективность их использования.

В статье рассмотрены сущность, особенности и значение финансового обеспечения вооруженных сил стран НАТО, что очень важно в условиях применения программно-целевого метода формирования и выполнения оборонного бюджета.

Ключевые слова: бюджет, оборонное планирование, бюджетные программы.

\section{Humeniuk R.}

\section{WORLD EXPERIENCE OF FINANCIAL SUPPORT MECHANISMS OF THE ARMED FORCES}

In the conditions of insufficient financing of the needs of the Ministry of Defense of Ukraine the development of the program-targeted method of budget planning becomes more urgent, since the emphasis is shifted from the need for funds to keep the armed forces on what results will be achieved from the use of budget funds, that is, the efficiency of their use is ensured.

The article deals with the nature, features and importance of financial support for the NATO military countries are considered, which is very important in the context of the application of the program-target method of formation and implementation of the defense budget.

Key words: budget, defense planning, budgetary programs.

Постановка проблеми. Фінансування потреб оборони країни $\epsilon$ критерієм iі зовнішньої безпеки. Оскільки такі видатки здебільшого фінансуються за рахунок державного бюджету, тобто через розподіл ВВП кожної країни, механізм фінансування, 
ефективність його інструментарію, бюджетний процес мають завжди актуальне значення як у мирні часи, та особливо, коли країна перебуває у стані війни. Внаслідок матеріалоємності та капіталоємності цієї сфери, складності прогнозування та планування, суттєвого значення та актуальності набуває дослідження світового досвіду розвитку механізмів фінансування збройних сил.

Це вимагає ретельного вивчення особливостей структури та функціонування добре апробованої у країнах НАТО системи оборонного планування, програмування та розроблення бюджету (ППБ), яка отримала найповніший розвиток в США.

Аналіз останніх досліджень та публікацій. Проблеми державної політики у сфері фінансування Збройних Сил України у своїх працях досліджували як вітчизняні, так і зарубіжні науковці. Досить вагомий внесок у дослідження цього питання зробили Л.Абалкін, Дж.Дентон, Р.Лукабо, Р.Міллер, Дж.Стігліц, В.Бережанський, В.Мунтіян.

Мета статті - висвітлити світовий досвід фінансового забезпечення функціонування збройних сил та доцільність й можливості його використання в Україні.

Виклад основного матеріалу. Формування оборонних бюджетів та загальний обсяг видатків, які виділяються на оборонні потреби країнами-членами НАТО, визначається такими факторами:

особливостями поточної зовнішньої політики;

станом економіки в країні та внутрішньою політичною ситуацією;

особливостями структури та функціонування оборонної системи;

положеннями чинної воєнної доктрини країни;

прийнятими міжнародними зобов'язаннями в оборонній сфері.

Фінансування більшості оборонних потреб здійснюється за рахунок державного бюджету[1,2]. Певна частина витрат фінансується за рахунок бюджетів інших рівнів. Заплановані видатки консолідованого бюджету країни на функціонування та подальший розвиток системи оборони країни на фінансовий рік складають оборонний бюджет країн. Його головною метою $\epsilon$ фінансове забезпечення функціонування всіх структурних елементів системи оборони країни, а саме:

збройних сил;

інших державних структур та організацій, від діяльності яких залежить функціонування та розвиток системи оборони країни;

військово-промислового комплексу;

оборонної інфраструктури;

стратегічного державного резерву на випадок воєнної загрози;

мобілізаційних потужностей державних організацій та структур цивільної оборони.

В ряді країн (головним чином країни Центральної та Східної Свропи та Туреччина) поширена практика фінансування частини оборонних потреб за рахунок коштів 3 державних та приватних фондів та іноземної фінансової допомоги. Кошти, витрачені протягом фінансового року з консолідованого бюджету країни, коштів спеціального фонду та фінансових організацій на потреби національної оборони, складають оборонні витрати країни[2].

Основною вимогою для всіх країн-членів НАТО щодо загальних витрат на потреби оборони є здійснення їх фінансування на рівні не менш як 2 \% від валового внутрішнього продукту. Оптимальний розподіл оборонних витрат на думку світових експертів має бути такий:

поточні витрати - 50 \%, з яких: утримання особового складу 25-40 \%; матеріальнотехнічне забезпечення військ та бойова підготовка 10-25\%;

капітальні витрати - 50 \%, 3 яких: закупівля озброєння та військової техніки 2025 \%, капітальне будівництво 15-20\%, НДДКР 5-10\%. 
Порядок планування, формування та затвердження бюджету оборонного відомства в країнах-членах НАТО є типовим і відрізняється лише термінами виконання окремих його етапів, що пов'язано з національними особливостями структури бюджетної системи, законодавчого органу і оборонного відомства країни та термінами початку фінансового року [2,3].

Досвід формування витрат оборону та оборонних бюджетів у країнах НАТО свідчить, що система Планування, Програмування, Розроблення бюджету та виконання (система ППБВ), яка започаткована у США знайшла широке застосування. Витрати на оборону у розглянутих країнах фінансуються в основному за рахунок коштів, які виділяються на оборону країни 3 державного бюджету. Разом 3 тим, деякі оборонні програми в окремих країнах можуть фінансуватись поза бюджетом[2,3].

Аналіз видатків різних країн світу на національну оборону в поєднанні з аналізом розміру видатків на утримання та іiі розвиток, дають інформацію стосовно рівня іiі обороноздатності та відповідно спроможності армії.

Різні дослідницькі структури по-різному оцінюють реальні розміри військових витрат держав світу. Розбіжності можуть бути досить значними. Приміром, щодо військових витрат Китаю $є$ три оцінки - 62,5 млрд. дол. (Міжнародний інститут стратегічних досліджень), 44,3 млрд. дол. (Стокгольмський інститут вивчення світу) і 81,4 млрд. дол. (ЦРУ) [3]. Військовий бюджет Росії також неможливо визначити досить точно: 21 млрд. дол. (оцінка ЦРУ), 61,9 млрд. дол. (Міжнародний інститут стратегічних досліджень) або 64,4 млрд. дол. (Стокгольмський інститут вивчення світу).

Відповідно до даних Світового банку, найбільші військові бюджети світу мають:

США - 648,8 млрд. дол.,

Китай - 250 млрд. дол.,

Індія - 66,51 млрд. дол.,

Франція - 63,8 млрд., дол.,

Росія - 61,39 млрд. дол.,

Великобританія - 49,99 млрд. дол.,

Німеччина - 49,47 млрд. дол.,

Японія - 46,62 млрд. дол.,

Південна Корея - 43,07 млрд. дол.,

Італія - 27,81 млрд. дол.

У першу двадцятку також входять Саудівська Аравія, Австралія, Туреччина, Бразилія, Іспанія, Канада, Ізраїль, Нідерланди, Тайвань і Мексика [4].

Бюджети на оборону в країнах НАТО мають певні цільові індикатори як щодо обсягів, так і їх структури: частка витрат на оборону має бути не меншою 2 \% від ВВП, а витрати на устаткування - не менше 20 \% від загальних витрат на оборону. Відмінність економічного розвитку у відповідних країнах визначає різний потенціал щодо наповнення оборонних бюджетів: чим нижчими $є$ економічні можливості, тим більший відсоток витрат припадає на частку фінансування військового персоналу (Табл.1).

Так, найбільше на ці цілі ресурсів спрямовує Португалія, Словенія та Чорногорія 72 \%, Греція - 71 \%, Албанія - 68 \%, Румунія - 53 \%. Середня по країнах НАТО - 52 \%. I, навпаки, суттєву частку бюджету на техніку та устаткування витрачають Норвегія - $27 \%$, США - $25 \%$, Нідерланди - $25 \%$, Іспанія - $23 \%$. 
Таблиця 1 - Показники витрат держави на оборону в країнах НАТО, 2018 рік

\begin{tabular}{|c|c|c|c|c|c|c|c|}
\hline Країна & $\begin{array}{c}\text { Витрати } \\
\text { на } \\
\text { устатку- } \\
\text { вання, \% }\end{array}$ & $\begin{array}{c}\text { Витрати } \\
\text { на } \\
\text { військовий } \\
\text { персонал, } \\
\text { \% }\end{array}$ & $\begin{array}{c}\text { Витрати } \\
\text { на інфра- } \\
\text { структуру, } \\
\%\end{array}$ & $\begin{array}{c}\text { Інші } \\
\text { витрати, } \\
\%\end{array}$ & $\begin{array}{c}\text { ВВП на } \\
\text { душу } \\
\text { населення, } \\
\text { тис. дол. } \\
\text { США }\end{array}$ & $\begin{array}{c}\text { Витрати } \\
\text { на } \\
\text { оборону } \\
\text { на душу } \\
\text { населення, } \\
\text { дол. США }\end{array}$ & $\begin{array}{c}\text { Частка } \\
\text { від } \\
\text { ВВП, } \\
\%\end{array}$ \\
\hline США & 25 & 39 & 1 & 35 & 54,4 & 1846 & 3,39 \\
\hline Греція & 12 & 71 & 0 & 16 & 23,7 & 526 & 2,22 \\
\hline Великобританія & 24 & 34 & 2 & 40 & 42,9 & 924 & 2,15 \\
\hline Естонія & 18 & 32 & 8 & 42 & 19,9 & 412 & 2,07 \\
\hline Польща & 27 & 46 & 4 & 24 & 15,9 & 325 & 2,05 \\
\hline Латвія & 35 & 32 & 8 & 24 & 16,4 & 333 & 2,03 \\
\hline Литва & 31 & 41 & 5 & 24 & 17,6 & 353 & 2 \\
\hline Румунія & 34 & 53 & 4 & 9 & 11,5 & 220 & 1,92 \\
\hline Франція & 24 & 47 & 4 & 26 & 43,4 & 788 & 1,82 \\
\hline Хорватія & 9 & 71 & 1 & 18 & 15,8 & 269 & 1,71 \\
\hline Туреччина & 32 & 45 & 2 & 21 & 15,5 & 253 & 1,64 \\
\hline Норвегія & 27 & 34 & 8 & 31 & 92,1 & 1489 & 1,62 \\
\hline Чорногорія & 10 & 72 & 3 & 16 & 8,2 & 128 & 1,55 \\
\hline Болгарія & 20 & 58 & 0 & 21 & 8,7 & 124 & 1,43 \\
\hline Нідерланди & 25 & 44 & 4 & 27 & 55 & 745 & 1,35 \\
\hline Португалія & 13 & 72 & 0 & 15 & 23,8 & 322 & 1,35 \\
\hline Канада & 13 & 49 & 4 & 34 & 51,9 & 641 & 1,23 \\
\hline Німеччина & 14 & 47 & 4 & 35 & 47,5 & 586 & 1,23 \\
\hline Данія & 13 & 46 & 2 & 38 & 62,7 & 758 & 1,21 \\
\hline Словакія & 22 & 55 & 2 & 21 & 20,7 & 251 & 1,21 \\
\hline Албанія & 11 & 68 & 1 & 20 & 5,1 & 59 & 1,16 \\
\hline Угорщина & 20 & 40 & 5 & 35 & 16,5 & 190 & 1,15 \\
\hline Італія & 21 & 66 & 2 & 11 & 35,3 & 406 & 1,15 \\
\hline Чехія & 12 & 55 & 5 & 27 & 23,4 & 260 & 1,11 \\
\hline Словенія & 8 & 72 & 0 & 19 & 26,7 & 272 & 1,02 \\
\hline Бельгія & 10 & 72 & 1 & 17 & 46,8 & 433 & 0,93 \\
\hline Іспанія & 23 & 57 & 0 & 19 & 33,2 & 310 & 0,93 \\
\hline Люксембург & 42 & 32 & 7 & 19 & 107,1 & 579 & 0,54 \\
\hline Середнє НАТО & 21 & 52 & 3 & 24 & 33,6 & & 2,36 \\
\hline
\end{tabular}

*Складено автором на основі джерел [4], [5]

Необхідно зазначити, що зв'язок витрат на оборону і рівнів економічного розвитку країн НАТО не $є$ однозначним (Рисунок 1). Серед країн, рівень доходів на душу населення яких перевищує середнє значення по країнах НАТО, але мають менше 2 \% оборонних витрат до ВВП, є Норвегія, Данія, Нідерланди, Німеччина, Франція, Бельгія, Італія, Іспанія. Навіть країни, які подолали 2 \% поріг (Греція, Великобританія, Польща, Естонія, Латвія, Литва), не досягають середнього рівня витрат по країнах Північноатлантичного Альянсу. 


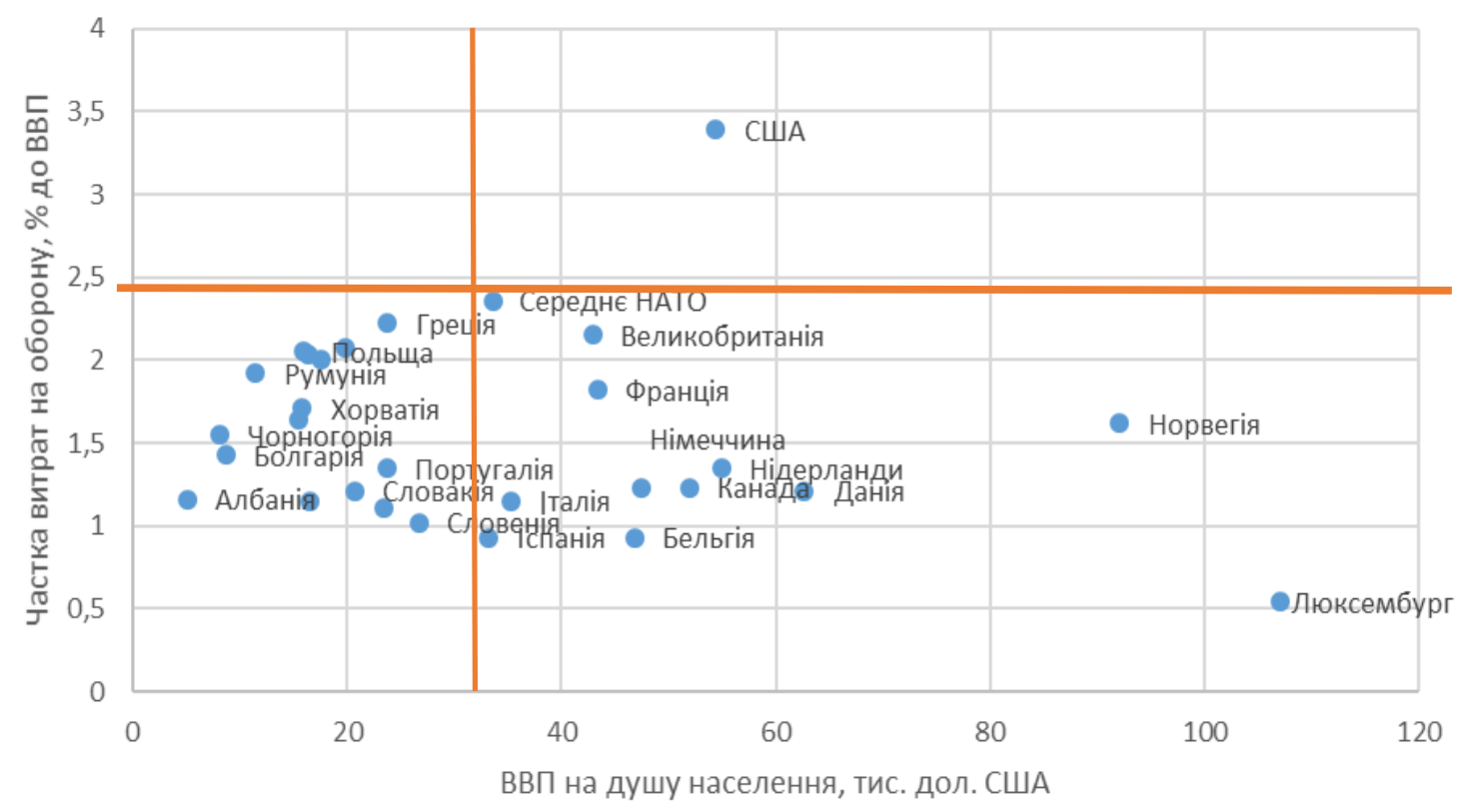

Рисунок 1 - Частка витрат на оборону країн НАТО у порівнянні із доходами на душу населення, 2018 р.

В США програмно-цільовий метод був спочатку запроваджений на рівні Федерального уряду, а сьогодні застосовується урядами штатів і міст. Всі штати США мають вимоги щодо застосування елементів програмно-цільового методу, в тому числі стратегічного планування, моніторингу і оцінки ефективності використання коштів. В той же час кожен штат має власний підхід при формуванні та виконанні бюджету, зокрема 3 використанням різних процедур для розробки показників виконання, звітності про ефективність виконання, а також для розподілу ресурсів між програмами.

При формуванні бюджетів за програмно-цільовим методом в США особлива увага надається здійсненню оцінки бюджетних програм та розробці грунтовних пропозицій щодо поводження з програмами. У зв'язку з цим розроблені спеціальні Інструкції (PART Instructions) щодо використання інструменту оцінки рейтингу програми, що представляє собою системний метод оцінки виконання програм Федерального уряду 3 метою підвищення їх результативності та визначення внеску програм у досягнення відповідною урядовою установою поставлених стратегічних та тактичних цілей.

У новій системі основна увага акцентується на виконанні затвердженого Конгресом США бюджету відповідно до бюджетного запиту Міністерства оборони в Президентському бюджеті.

Система ППБВ стала внутрішньою методологією Міністерства оборони i використовується для визначення обсягів бюджетного фінансування, потрібних для виконання покладених на нього завдань i запропонованих для включення до Президентського бюджету, який подається Конгресу. Вона дає уявлення військовому командуванню про оптимальне співвідношення між витратами на потрібну структуру збройних сил, їх оснащення та утримання в межах встановлених фінансових обмежень.

У концентрованому вигляді результати реалізації процесу ППБВ відображаються у внутрішньому робочому документі - Оборонній програмі на майбутні роки (ОПМР), яка розробляється міністерством оборони. Вона є комп'ютеризованою базою даних про збройні сили, ресурси та їх оснащення, пов'язані з усіма програмами міністерства оборони. 
У загальному вигляді структура ОПМР складається з “блоків”, розташованих послідовно в трьох основних вимірах (рис. 2).

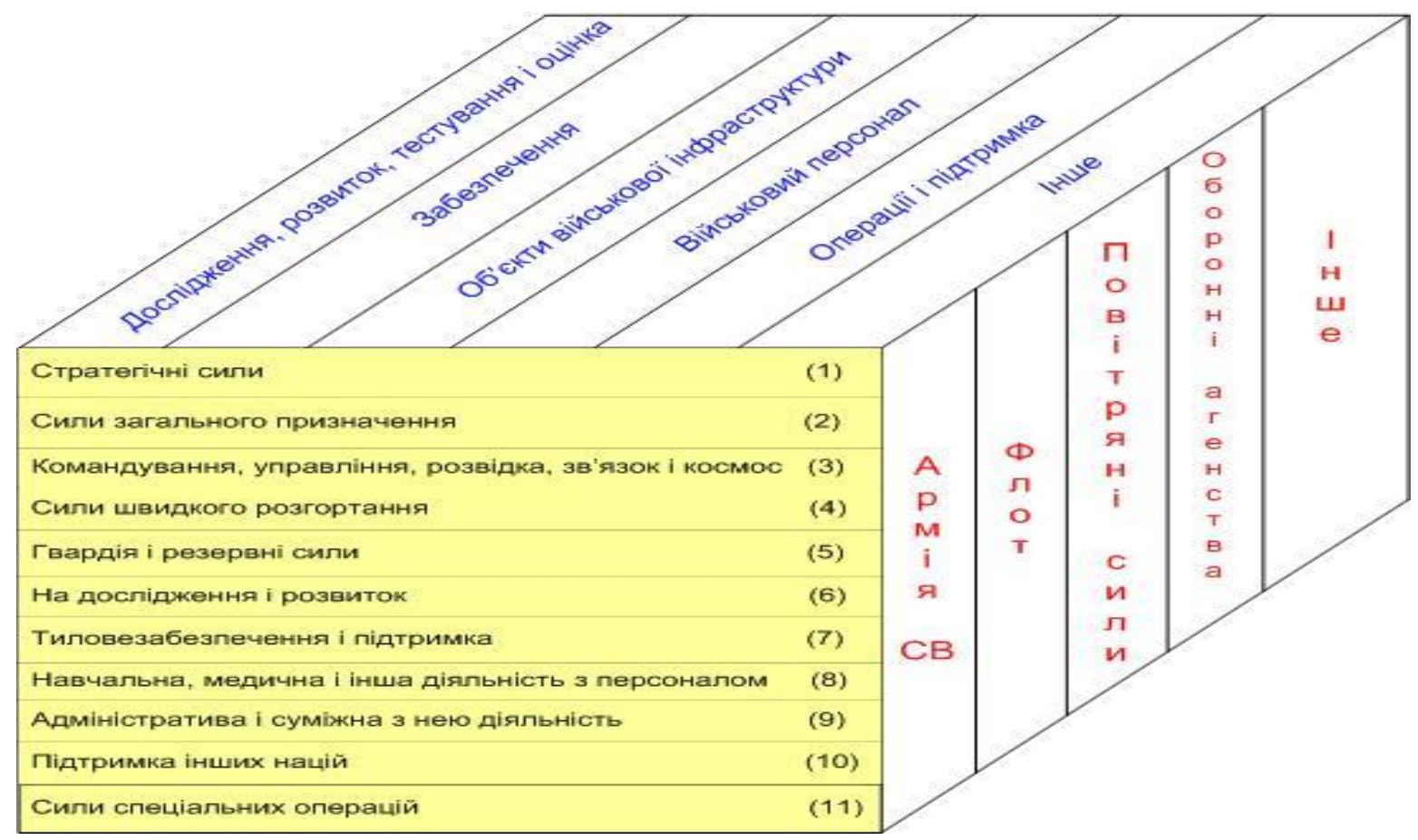

Рисунок 2 - Оборонні програми міністерства оборони США і асигнування конгресу

На фінансовий рік до ОПМР включаються сумарні ресурси міністерства оборони та інформація про збройні сили за попередній, на поточний, наступні бюджетні роки та ще чотири наступні роки.

Процес ППБВ проводиться шляхом послідовного виконання етапів планування, програмування та розробки бюджету, прийняття бюджету і контролю його виконання. Планування є першим етапом процесу розподілу ресурсів міністерства оборони, в ході якого визначаються можливості, потрібні для стримування та ліквідації загроз. Особливістю $€$ те, що у США він починається за три роки до початку фінансового року, на який плануються бюджетні асигнування, а закінчується випуском нормативного документа Керівництва з об'єднаного програмування (КОП) на поточні роки. Взагалі ж, прогноз видатків збройних сил здійснюється на 6 років. Після завершення процедур планування i програмування міністерство оборони затверджує дворічний бюджет, у якому перші два роки шестирічного періоду ОПМР подаються до Конгресу США як повноцінні “самостійні” бюджети.

Міністерство національної оборони Румунії свою діяльність у фінансовій сфері здійснює відповідно до прийнятої стратегії національної безпеки та розробленої на іiі основі воєнної стратегії. 3 метою оптимізації та підвищення ефективності використання бюджетних коштів за безпосередньою участю та під контролем фахівців США в Румунії була створена інтегрована система планування програмування фінансування та оцінки оборонних витрат, яка відповідає основним вимогам Альянсу. 
Відповідно до існуючої системи вся робота з формування, затвердження бюджету Міністерства національної оборони здійснюється в 3 етапи.

Перший етап - планування, основним завданням якого $\epsilon$ визначення рівня мінімально необхідних потреб фінансування оборонного відомства.

Другий етап - програмування. На цьому етапі здійснюється визначення основних програм фінансування, їх подальша деталізація на субпрограми та розробляється проект бюджету Міністерства національної оборони.

Третій етап - бюджетування. Головною метою цього етапу є переконання уряду країни в доцільності реалізації запланованих програм та оптимальності визначених рівнів ї фінансування. Результатом цього етапу є затвердження проекту бюджету Міністерства національної оборони як окремого розділу державного бюджету країни.

У Румунії існують три рівня фінансування оборонних потреб:

Міністерство національної оборони (розпорядник коштів);

департаменти, які підпорядковані міністру національної оборони;

армійські корпуси, бригади та інші військові частини.

Основним завданням двох перших рівнів фінансування $є$ розподіл бюджетних асигнувань. На третьому рівні виділені кошти використовуються.

Бюджет Міністерства оборони Болгарії розробляється експертами дирекції планування і управління бюджетом Міністерства оборони у співробітництві з експертами інших підрозділів міністерства, зокрема дирекції оборонного планування та прогнозування. Робота щодо розробки бюджету здійснюється під безпосереднім керівництвом заступника міністра з питань бюджету та управління фінансами і майном.

На попередньому етапі проводиться аналіз усієї наявної інформації щодо витрат минулого року та можливих втрат на наступний рік, при цьому враховуються такі чинники: процеси реформування армії; заплановані структурні зміни та скорочення кількості підрозділів і особового складу; кількість національних та міжнародних навчань; участь у спільних операціях під егідою НАТО, ООН, ОБСЄ; пріоритетні проекти модернізації озброєння та військової техніки та відсоток їх виконання на наступний рік; підвищення рівня соціального захисту військовослужбовців та членів їх сімей; макроекономічні показники розвитку країни; передбачений рівень інфляції та інше.

На підставі вищезазначеного розробляється проект бюджету військового відомства на наступний рік.

Планування бюджету Міністерства Національної Оборони (МНО) Туреччини розпочинається на початку року. Для виконання цього завдання в організаційно - штатній структурі МНО Туреччини створене Головне фінансове управління. Робота над бюджетом проводиться згідно із спеціальною програмою планування бюджету. Бюджет розподіляється на 3 витратні частини: поточні витрати, капіталовкладення і трансфери.

Генеральний штаб Збройних Сил Туреччини визначає поточний рівень бойової готовності військ та визначає нагальну потребу збройних сил у придбанні нових систем озброєння та інтенсивність заходів бойової підготовки і як пропозиції до бюджету на наступний рік надсилає до МНО Туреччини.

МНО Туреччини узагальнює всі пропозиції (із врахуванням потреб центрального апарату МНО) та направляє проект бюджету МНО Туреччини до Міністерства фінансів країни.

Слід також зазначити що фінансування ряду оборонних програм здійснюється поза бюджетом МНО Туреччини. В першу чергу, це програми модернізації певних видів озброєння, які здійснюються за окремими угодами та спеціальними рішеннями уряду. 
Висновки. Програмно-цільове складання бюджету забезпечує інформацією щодо ефективності, з якою Міністерство оборони України використовує ресурси, і дає відповіді на запитання:

- про цілі, які ставить перед собою Міністерство оборони, та можливість формування набору програм, пов'язаних з цими цілями;

- про поточні й очікувані оперативні цикли ресурсних витрат на виконання кожної програми;

- про результати або кінцеві цілі кожної програми;

- про існування альтернативних методів забезпечення кожної програми та витрати, які для цього плануються.

Слід зазначити, що при розробленні та запровадженні основних принципів програмно-цільового методу варто пам'ятати що:

- запровадження програмно-цільового методу передбачає наявність ефективної системи фінансового контролю, звітності та аудиту;

- у деяких випадках вплив програми може виявити себе лише через якийсь час після виконання певних завдань програми (або програми в цілому), i тому інколи результативність окремих етапів реалізації програми може бути непоказовою або помилковою;

- програмно-цільовий метод впроваджується поступово: окремі його елементи спочатку вводяться й перевіряються, а 3 часом, тобто 3 розвитком самого процесу бюджетування, модифікуються;

- майже всі країни, що переходили до програмно-цільового бюджетування, мали складнощі, пов'язані 3 недооцінкою поставлених завдань, браком спеціально підготовленого персоналу та підтримуючих інформаційних систем.

На сьогоднішній день найбільш доцільно здійснювати удосконалення структури кошторису Міністерства оборони на основі формування цілей оборонних програм за функціональними складовими збройних сил. Аналіз досвіду існуючого взаємозв'язку між оборонним та бюджетним планування в збройних силах провідних країн світу свідчить, що такий підхід реалізований в більшості з них (США, Франція, Велика Британія тощо). Визначення програмних витрат за оборонними програмами здійснюється на основі основних видів витрат, які визначені в тій чи іншій країні. До них можуть належати, наприклад: утримання особового складу, закупівля та витрати на утримання ОВТ, проведення НДДКР.

Такий підхід до побудови структури кошторису Міністерства оборони, як і попередній варіант має низку значних переваг щодо існуючої системи оборонного та бюджетного планування. Головне - $\epsilon$ визначена ціль за кожною із оборонних програм та за запропонованим порядком побудови витратної частини кошторису формуються його вартісні показники, які дозволяють чітко і прозоро визначити, що можна зробити для досягнення поставлених цілей за виділеними коштами не тільки на рівні збройних сил взагалі, а й за окремим військовим формуванням. Також така структура кошторису дозволить мати маневр коштами на випадок зміни ситуації як в фінансуванні, так і під час зміни цілей та завдань. За такою структурою формується така система показників кошторису, яка дозволить оцінити ефективність планування та використання коштів за призначенням.

За умови застосування такого підходу до переваг можна віднести дотримання принципу програмно-цільового планування та витрачання бюджетних коштів, а також такий підхід не потребує достатньо значної зміни процесів оборонного та бюджетного планування в Збройних Силах України. 
Необхідною умовою ефективного складання бюджету є запровадження наступних заходів:

- здійснення поступових структурних змін 3 метою забезпечення раціонального використання бюджетних коштів;

- створення системи оцінювання результативності бюджетних програм на основі безпосередніх показників їх виконання та ефективності діяльності бюджетних установ i організацій, що надають бюджетні послуги, за кінцевими результатами.

Для ефективного використання бюджетних ресурсів та досягнення результатів в процесі формування бюджету за програмно-цільовим методом відповідальним виконавцям бюджетних програм варто:

- схвалити результативні показники виконання паспортів бюджетних програм для Міністерства оборони та список оптимально необхідних показників для оцінки результативності;

- забезпечити збір статистичних даних, необхідних для надання адекватної оцінки результативності програм та перевірку незалежності поданих даних;

- забезпечити проведення навчання та підвищення спроможності всіх учасників бюджетного процесу до формування бюджету за програмно-цільовим методом;

- визначити інші кроки, необхідні для ефективного впровадження програмноцільового методу формування та виконання державного бюджету.

\section{Література:}

1. Бережанський В.Г., Гайворонський О.С., Луцик I.C. Формування оборонного бюджету Сполучених Штатів Америки. Київ. 2004. 21 с.

2. Мунтіян В.І. Економіка та оборонні витрати: аналіз зарубіжних досліджень і український шлях розвитку. К.: НДФІ, 1998. 464 с.

3. Stockholm International Peace Research Institute (SIPRI). URL: http://www.sipri.org/research

4. Office of the under secretary of Defense (Comptroller). Budget Materials. URL: http://www.comptroller.defense.gov

5. German Defense Spending From 2016. URL: http://www.bloomberg.com/ news/articles/2014-10-23/german-lawmakers-seek-to-raise-defense-spending

6. Under Secretary of Defense (Comptroller). United States Department Of Defense Fiscal Year 2016 Budget Request. URL: http://www.budget.mil

7. Latvia's defense spending in 2015 will reach 1 percent of GDP. URL: http://www.sargs.lv/Zinas/Military_News/2014/12/18-01.aspx\#lastcomment

8. UK's armed forces face new spending crunch. URL:http://www.theguardian.com/uknews/defence-and-security-blog/2014/nov/ 10/british-army-defence-budget

9. Daily Hansard - Debate URL:http://www.publications.parliament.uk 